\title{
Correction to: The association between mothering behaviors and empathy in European-American and Asian-American emerging adults
}

\author{
Achu Johnson Alexander ${ }^{1}$ (D) Joseph Bechhofer ${ }^{2} \cdot$ Carolyn McNamara Barry $^{2} \cdot$ Jason Prenoveau $^{2} \cdot$ Beth Kotchick $^{2}$
}

(C) Springer Science+Business Media, LLC, part of Springer Nature 2022

\section{Correction to: Current Psychology (2021)} https://doi.org/10.1007/s12144-021-02139-y

The original version of this article unfortunately contained a mistake. Columns for Tables 1, 2 and 3 are misaligned and some entries went missing. Thus this erratum is presented to fix the error.

The original article has been corrected.

Publisher's Note Springer Nature remains neutral with regard to jurisdictional claims in published maps and institutional affiliations.

The online version of the original article can be found at https://doi.org/ $10.1007 / \mathrm{s} 12144-021-02139-\mathrm{y}$

Achu Johnson Alexander aalexander@annamaria.edu

1 Department of Psychology, Anna Maria College, 50 Sunset Lane Box 61, Paxton, MA 01612, USA

2 Department of Psychology, Loyola University, Baltimore, MD, USA 